\title{
Valuing Health Effects of Natural Radionuclides Releases from Yatağan Power Plant
}

\author{
Tayfun BÜKE ${ }^{1}$, Aylin Çiğdem KÖNE ${ }^{2}$ \\ ${ }^{1}$ Department of Physics, Muğla University, Muğla, Turkey \\ ${ }^{2}$ Department of Economics, Muğla University, Muğla, Turkey \\ Email:tbuke@mu.edu.tr
}

\begin{abstract}
The objective of this paper is the valuation of radiological health effects of Yatağan Power Plant. To this aim the radiation dose calculations are carried out for the population living within $80 \mathrm{~km}$ radius of the plant. The average of the maximum measured specific isotopes ${ }^{238} \mathrm{U},{ }^{232} \mathrm{Th}$ and ${ }^{226} \mathrm{Ra}$ in the flying ash samples are considered as radioactive sources. Based on the dose calculations, first the stochastic health effects and then monetary health effects are estimated. The estimated total collective dose and economic value of the predicted health effects are $0.3098 \mathrm{man} \mathrm{Sv} / \mathrm{y}$ and $14791 \mathrm{US} \$ \mathrm{y}$ respectively. The results obtained from the dose calculations are lower than the limits of International Commission of Radiation Protection (ICRP) and it does not pose any risk for public health. Monetary value of health risks is also negligible in comparison to the average yearly sales revenue of the plant which is 250 million US\$.
\end{abstract}

Keywords: coal-fired power plants, collective dose, atmospheric dispersion, valuing health effects

\section{Introduction}

Yatağan Power Plant (YPP) is one of the largest lignitefired power plants in Turkey with a total capacity of 630 MW. It has been operated in Muğla province at the western Anatolia since 1982 [1]. Lignite in Muğla province contains some uranium as all lignite does. That uranium passes to ash with a higher concentration during the firing process in furnace chamber at $1000{ }^{\circ} \mathrm{C}$. While wellurned ash goes to the plant chimney, the others are not burned perfectly, which are called slag ashen drops the furnace chamber floor [2,3]. The radioactive flying ash is released to the atmosphere, depending on the efficiency of the plant's chimney emission control equipment. The major potential pathway, which might result in increased radiation doses to people are inhalation of flying ash, ingestion of food grown in contaminated soil or direct radiation exposure from the increased deposited radioactivity when flying ash are released from the plant chimney $[4,5]$.

In this study, the radiation dose calculations have been carried out using the code CAP88-PC which stands for Clean Air Act Assessment Package [6] for the population living within $80 \mathrm{~km}$ radius of the YPP by using the average of the maximum measured specific isotopes ${ }^{238} \mathrm{U}$, ${ }^{232} \mathrm{Th}$ and ${ }^{226} \mathrm{Ra}$ in the flying ash samples as radioactive sources. Based on the dose calculations, the stochastic health effects have been estimated by using the risk factors, as recommended by the International Commission of Radiation Protection (ICRP) [7]. Then the predicted health effects have been monetized by using the methodology given in NucPacts model [8].

In order to estimate the average dispersion of radionuclides released from a point source, a modified plume dispersion model has been used in the calculations. Pasquill categories A-F with site-specific averaged meteorological conditions are used in the modified dispersion model. The meteorological data on atmospheric stability conditions like mean wind speed and the frequency distribution of wind direction are obtained from Turkish State Meteorological Service [9]. The population distribution around the YPP is taken from Turkish State Institute of Statistics [10].

Annual radioactivity release rate for three different radionuclides in the dose calculations is calculated by using the ash emission rate from the plant chimney, the measured activity in flying ash and the plant loading factor $[11,12]$.

The rest of the study is organized as follows. Section 2 introduces the source terms for ${ }^{238} \mathrm{U},{ }^{232} \mathrm{Th}$ and ${ }^{226} \mathrm{Ra}$. Section 3 deals with the assessment of radiation hazard. In Section 4 risk calculations are given in detail. Section 5 presents a monetary valuation of health effects. Finally, Section 6 gathers the main conclusions derived from this paper.

\section{Source Terms}

In this study, the literature related to the maximum measured specific isotopes ${ }^{238} \mathrm{U},{ }^{232} \mathrm{Th}$ and ${ }^{226} \mathrm{Ra}$ in the flying ashes of the YPP are reviewed. In those studies, the concentrations of ${ }^{238} \mathrm{U},{ }^{232} \mathrm{Th}$ and ${ }^{226} \mathrm{Ra}$ have been 
measured with high-resolution gamma spectroscopy. The maximum radionuclides concentrations in flying ashes of the YPP are presented in Table 1 [13-15]. As seen from Table 1 the measured concentrations are different from each other and the average of the maximum measured concentrations of different studies for ${ }^{238} \mathrm{U},{ }^{232} \mathrm{Th}$ and

${ }^{226} \mathrm{Ra}$ are $854,191,286 \mathrm{~Bq} / \mathrm{kg}$ respectively. This is an expected result since the natural radionuclides content in the flying ashes of a coal fired power plant depend on the quality of the coals burned in the power plant. The radionuclides concentrations can be changed up to 1 and 2 orders in magnitude according to the coal types used in the power plant [2].

In this study, the average of the maximum measured specific isotopes ${ }^{238} \mathrm{U},{ }^{232} \mathrm{Th}$ and ${ }^{226} \mathrm{Ra}$ in the flying ash samples are used as radioactive sources for the potential worst-case scenario.

\section{Assessment of Radiation Hazard}

The radiation dose calculations have been carried out by the code CAP88-PC for the population living within 80 $\mathrm{km}$ radius of the YPP by using the average of the maximum measured specific isotopes ${ }^{238} \mathrm{U},{ }^{232} \mathrm{Th}$ and ${ }^{226} \mathrm{Ra}$ in the flying ash samples as radioactive sources.

The CAP88-PC (which stands for Clean Air Act Assessment Package) computer code is a set of computer programs, databases and associated utility programs for estimation of dose and risk from radionuclide emissions to air on a personal computer. It uses a modified Gaussian plume equation to estimate the average dispersion of radionuclides released from up to six emitting sources for a circular grid of distances and directions for a radius of up to $80 \mathrm{~km}$ around the facility. The sources may be either elevated stacks, such as a smokestack, or uniform area sources, such as a pile of uranium mill tailings. Plume rise can be calculated assuming either a momentum or buoyant-driven plume. The plume centerline remains at effective stack height unless gravitational settling of particulates produces a downward tilt, or until meteorological conditions change. Radionuclides are depleted from the plume by precipitation scavenging, dry deposition and radioactive decay. The stored depletion fractions were calculated numerically with a Simpson's rule. Ground surface and soil concentrations are calculated for those nuclides subject to deposition due to dry deposition and precipitation scavenging. Agricultural

Table 1. Concentrations of natural radionuclides in flying ashes of the YPP $(\mathrm{Bq} / \mathrm{kg})$

\begin{tabular}{cccc}
\hline Reference number & ${ }^{238} \mathrm{U}$ & ${ }^{232} \mathrm{Th}$ & ${ }^{226} \mathrm{Ra}$ \\
\hline$[13]$ & 375 & 253 & 63 \\
{$[14]$} & 1704 & 178 & 122 \\
{$[15]$} & 484 & 141 & 672 \\
Average & $\mathbf{8 5 4}$ & $\mathbf{1 9 1}$ & $\mathbf{2 8 6}$ \\
\hline
\end{tabular}

arrays of milk cattle, beef cattle and agricultural crop area are generated automatically, requiring the user to supply only the agricultural productivity values. Only 7 organs are valid for the effective dose equivalent. They are Gonads $25 \%$, Breast $15 \%$, Red marrow 12\%, Lungs $12 \%$, Thyroid 3\%, Endost 3\% and Remainder $30 \%$. Doses are provided for the pathways of ingestion and inhalation intake, ground level air immersion and ground surface irradiation. Particle size, clearance class and gut-to-blood transfer factors of the released nuclide type are further break down factors. These factors are stored in a database for use by the program.

\subsection{Input Data}

The estimate of radioactivity released annually in the environment by the YPP has been carried out for ${ }^{238} \mathrm{U}$, ${ }^{232} \mathrm{Th}$ and ${ }^{226} \mathrm{Ra}$ that, according to average of the maximum measured concentrations given in the literature, have resulted to be the most significant. Annual nuclide release rate for the radionuclide type $i\left[Q_{i}: \mathrm{Bq} / \mathrm{y}\right]$ is calculated from the relation given by:

$$
Q_{i}=\dot{m} A_{i} L
$$

where $\dot{m}$ is the ash emission rate from the plant chimney $(\mathrm{kg} / \mathrm{y}), A_{i}$ is the average of the maximum measured radionuclide type $i$ in flying ash $(\mathrm{Bq} / \mathrm{kg})$ and $L$ is the plant loading factor.

Plume rise is calculated by using the momentum plume model since ash emission velocity at the chimney exit is known. An average lid for the assessment area is provided as part of the input data. The agricultural data like beef cattle density, milk cattle density and land fraction cultivated for vegetable crop and others for the region are inputted to the code in order to estimate of emitted radionuclides into the food chain.

The meteorological data which obtained from Turkish State Meteorological Service [9] are processed to find out the stability array file for 16 directions. The atmospheric dispersion of the radionuclides from the stack of a power plant are strongly depends on the meteorological conditions where the power plant is located. Therefore the meteorological data are annually averaged within hourly time step for the each year of the period 19752006. The better estimation has been made in dose calculations by this way.

The stability array file consists of 4 different wind frequencies, one for each of the 16 wind directions and 6 Pasquill stability category (A-F). 16 records are entered for each Pasquill stability category and wind frequencies. Pasquill stability classes used in the code are A) extremely unstable, B) unstable, C) slightly unstable, D) neutral, E) slightly stable, and F) stable. Once a stability array file has been prepared, and it is converted to wind file for input to the CAP88-PC code which is namely 


\section{MUGLA. WND.}

Population distribution in the $80-\mathrm{km}$ radius of the plant is presented Table $2[10]$ and the dose calculations are made for those population. The program uses a population file for dose calculations. The population file contains the location description, latitude, and longitude of the facility, the number of distances and population for each distance according to 16 wind directions in counterclockwise order starting with North. The distances are edge points of each sector and are entered in the population file in $\mathrm{km}$. The population distribution file which is namely MUGLA.POP is prepared for 20 distances of each wind direction. Those 20 distances are chosen closest values to the distances presented in Table 2, which are the exact values around the plant to get the sensible results for dose calculations.

Input parameters used in the calculations are given in Table 3 [1,16-18]. Calculated collective effective dose equivalent rate values including all radionuclides and pathways effect around the plant by CAP88-PC code are presented Table 4.

\section{Risk Calculation}

The occurrence of each of the main stochastic health effects (i.e. fatal and non-fatal cancers and severe hereditary effects) arising as a result of routine atmospheric emission from a power plant is calculated as [8],

$$
N_{h}=H R_{h}
$$

where $N_{h}$ is the total occurrence of health effect, $h$ (cases/y), $H$ is the total collective dose occurring via all pathways (man Sv/y), $R_{h}$ is the risk factor for health effect $h$ (cases man $/ \mathrm{Sv})$.

The calculated health effects by the risk factors in CAP88-PC computer code are lower than the calculated health effects by the risk factors which are recommended by the ICRP [7]. Therefore in this study, the ICRP's risk factors have been used in calculations for the potential worst-case scenario. Those values are given in Table 5. The total stochastic health effects around the YPP which are calculated from Equation (2) are given in Table 6.

Table 2. Population distribution in the $80-\mathrm{km}$ radius of the YPP

\begin{tabular}{|c|c|c|c|}
\hline Location name & Population & Distance to plant $(\mathrm{km})$ & Direction \\
\hline Yatağan & 46252 & 3 & $\mathrm{~N}$ \\
\hline Çine & 53770 & 32 & $\mathrm{~N}$ \\
\hline Köşk & 25321 & 65 & $\mathrm{~N}$ \\
\hline Sultanhisar & 22795 & 66 & $\mathrm{~N}$ \\
\hline Aydın, Merkez & 208341 & 46 & NNW \\
\hline Koçarlı & 37167 & 53 & NNW \\
\hline İncirliova & 40733 & 70 & NNW \\
\hline Germencik & 45821 & 75 & NNW \\
\hline Karpuzlu & 13207 & 37 & NW \\
\hline Söke & 137739 & 70 & NW \\
\hline Milas & 112808 & 28 & W \\
\hline Didim & 37395 & 71 & W \\
\hline Bodrum & 97826 & 68 & WSW \\
\hline Datça & 13914 & 77 & WSW \\
\hline Marmaris & 79302 & 55 & S \\
\hline Muğla, (center) & 83511 & 26 & SE \\
\hline Ula & 21944 & 44 & SE \\
\hline Köyceğiz & 29196 & 66 & SE \\
\hline Ortaca & 35670 & 77 & SE \\
\hline Beyağaç & 7332 & 72 & ESE \\
\hline Kale & 21390 & 61 & $\mathrm{E}$ \\
\hline Tavas & 60669 & 80 & $\mathrm{E}$ \\
\hline Kavaklidere & 12548 & 25 & ENE \\
\hline Babadağ & 8212 & 80 & ENE \\
\hline Karacasu & 21980 & 65 & $\mathrm{NE}$ \\
\hline Bozdoğan & 35190 & 44 & NNE \\
\hline Yenipazar & 15492 & 51 & NNE \\
\hline Nazilli & 145963 & 67 & NNE \\
\hline Kuyucak & 31094 & 81 & NNE \\
\hline Total & 1502582 & & \\
\hline
\end{tabular}


Table 3. Input parameters used in the calculation

\begin{tabular}{lc}
\hline \multicolumn{1}{c}{ Explanation } & Values \\
\hline Grid distances, $(\mathrm{m})$ & $3000,14500,26500,35000,45000,54000$, \\
Annual precipitation in Yatağan, $(\mathrm{cm} / \mathrm{y})$ & $61000,67000,73000,78000$ \\
Annual ambient temperature in Yatağan, $\left({ }^{\circ} \mathrm{C}\right)$ & 64.96 \\
Annual average wind speed in Yatağan, $(\mathrm{m} / \mathrm{s})$ & 16.20 \\
Height of lid, $(\mathrm{m})$ & 2 \\
Chimney height, $(\mathrm{m})$ & 642 \\
Chimney inner diameter at the exit, $(\mathrm{m})$ & 120 \\
Ash emission velocity at the chimney exit, $(\mathrm{m} / \mathrm{s})$ & 6.4 \\
Ash emission rate from the chimney, $(\mathrm{kg} / \mathrm{y})$ & 4.1 \\
Plant loading factor $(\%)$ & $7.55 \times 10^{6}$ \\
Average of the maximum measured activity in flying ash $\left({ }^{238} \mathrm{U} \mathrm{U}^{232} \mathrm{Th}\right.$, & 75 \\
$\left.{ }^{226} \mathrm{Ra}\right)(\mathrm{Bq} / \mathrm{kg})$ & $854,191,286$ \\
Annual nuclide release rate, $(\mathrm{Bq} / \mathrm{y})$ & $4.84 \mathrm{x} 10^{9}, 1.08 \times 10^{9}, 1.62 \times 10^{9}$ \\
Human inhalation rate, $(\mathrm{cm} / \mathrm{hr})$ & $9.17 \times 10^{5}$ \\
Land fraction cultivated for vegetable crops & $5.50 \mathrm{x} 10^{-2}$ \\
Beef cattle density, $\left(\right.$ number $\left./ \mathrm{km}{ }^{2}\right)$ & 3.89 \\
Milk cattle density, $\left(\right.$ number $\left./ \mathrm{km}{ }^{2}\right)$ & 1.13 \\
Meat ingestion per person, $(\mathrm{kg} / \mathrm{y})$ & 15 \\
Leafy vegetable ingestion per person, $(\mathrm{kg} / \mathrm{y})$ & 140 \\
Cereals ingestion per person, $(\mathrm{kg} / \mathrm{y})$ & 228 \\
Milk ingestion per person, $(\mathrm{L} / \mathrm{y})$ & 33 \\
\hline
\end{tabular}

Table 4. Collective effective dose equivalent (man Sv/y)

\begin{tabular}{|c|c|c|c|c|}
\hline Distance, $\mathrm{km}$ & $\mathrm{N}$ & NNW & NW & WNW \\
\hline 3.00 & 0.0480 & 0.0000 & 0.0000 & 0.0000 \\
\hline 14.50 & 0.0000 & 0.0000 & 0.0000 & 0.0000 \\
\hline 26.50 & 0.0000 & 0.0000 & 0.0000 & 0.0000 \\
\hline 35.00 & 0.0081 & 0.0000 & 0.0040 & 0.0000 \\
\hline 45.00 & 0.0000 & 0.0390 & 0.0000 & 0.0000 \\
\hline 54.00 & 0.0000 & 0.0060 & 0.0000 & 0.0000 \\
\hline 61.00 & 0.0000 & 0.0000 & 0.0000 & 0.0000 \\
\hline 67.00 & 0.0050 & 0.0000 & 0.0000 & 0.0000 \\
\hline 73.00 & 0.0000 & 0.0110 & 0.0230 & 0.0000 \\
\hline 78.00 & 0.0000 & 0.0000 & 0.0000 & 0.0000 \\
\hline Distance, $\mathrm{km}$ & $\mathrm{W}$ & WSW & SW & SSW \\
\hline 3.00 & 0.0000 & 0.0000 & 0.0000 & 0.0000 \\
\hline 14.50 & 0.0000 & 0.0000 & 0.0000 & 0.0000 \\
\hline 26.50 & 0.0510 & 0.0000 & 0.0000 & 0.0000 \\
\hline 35.00 & 0.0000 & 0.0000 & 0.0000 & 0.0000 \\
\hline 45.00 & 0.0000 & 0.0000 & 0.0000 & 0.0000 \\
\hline 54.00 & 0.0000 & 0.0000 & 0.0000 & 0.0000 \\
\hline 61.00 & 0.0000 & 0.0000 & 0.0000 & 0.0000 \\
\hline 67.00 & 0.0000 & 0.0120 & 0.0000 & 0.0000 \\
\hline 73.00 & 0.0055 & 0.0000 & 0.0000 & 0.0000 \\
\hline 78.00 & 0.0000 & 0.0015 & 0.0000 & 0.0000 \\
\hline Distance, $\mathrm{km}$ & $\mathrm{S}$ & SSE & $\mathrm{SE}$ & ESE \\
\hline 3.00 & 0.0000 & 0.0000 & 0.0000 & 0.0000 \\
\hline 14.50 & 0.0000 & 0.0000 & 0.0000 & 0.0000 \\
\hline 26.50 & 0.0000 & 0.0000 & 0.0260 & 0.0000 \\
\hline 35.00 & 0.0000 & 0.0000 & 0.0000 & 0.0000 \\
\hline 45.00 & 0.0000 & 0.0000 & 0.0048 & 0.0000 \\
\hline 54.00 & 0.0150 & 0.0000 & 0.0000 & 0.0000 \\
\hline
\end{tabular}




\begin{tabular}{ccccc}
\hline Distance, $\mathrm{km}$ & $\mathrm{N}$ & $\mathrm{NNW}$ & $\mathrm{NW}$ & $\mathrm{WNW}$ \\
\hline 61.00 & 0.0000 & 0.0000 & 0.0000 & 0.0000 \\
67.00 & 0.0000 & 0.0000 & 0.0045 & 0.0000 \\
73.00 & 0.0000 & 0.0000 & 0.0000 & 0.0050 \\
78.00 & 0.0000 & 0.0000 & $\mathrm{NE}$ & 0.0000 \\
\hline Distance, km & $\mathrm{E}$ & $\mathrm{ENE}$ & 0.0000 & 0.0000 \\
3.00 & 0.0000 & 0.0000 & 0.0000 & 0.0000 \\
14.50 & 0.0000 & 0.0000 & 0.0000 & 0.0000 \\
26.50 & 0.0000 & 0.0027 & 0.0000 & 0.0000 \\
35.00 & 0.0000 & 0.0000 & 0.0000 & 0.0039 \\
45.00 & 0.0000 & 0.0000 & 0.0000 & 0.0016 \\
61.00 & 0.0000 & 0.0000 & 0.0000 & 0.0000 \\
73.00 & 0.0034 & 0.0000 & 0.0023 & 0.0140 \\
\hline
\end{tabular}

Table 5. Risk factors for main stochastic health effects for whole population (case/man Sv)

\begin{tabular}{lc}
\hline \multicolumn{1}{c}{ Health Effect } & Risk factor \\
\hline Fatal cancer & $5.0 \times 10^{-2}$ \\
Non fatal cancer & $1.0 \times 10^{-2}$ \\
Severe hereditary effects & $1.3 \times 10^{-2}$ \\
\hline
\end{tabular}

Table 6. The total stochastic health effects (cases/y)

\begin{tabular}{lc}
\hline \multicolumn{1}{c}{ Health effect type } & Number of cases \\
\hline Fatal cancer & $1.549 \times 10^{-2}$ \\
Non fatal cancer & $3.098 \times 10^{-3}$ \\
Severe hereditary effects & $4.027 \times 10^{-3}$ \\
\hline
\end{tabular}

\section{Monetary Unit Costs for Health Impact Assessments}

The final stage of the impact pathway analysis is to value the health endpoints in money terms. In literature there are two approaches that may be used in health risk assessments; the first is based on the Value of a Statistical Life (VOSL) and the second is based on the Value of a Life Year Lost (VLYL) [19]. The latter differs from the former in that it takes into account the latency period of different types of cancers. A component related to the cost of illness has also been included in VLYL. Estimates for the economic unit value of radiological health effects have been made for several countries. Ideally, economic unit values should be based on local economic valuation of a country. However, in the absence of such information economic unit values for specific to a country may be transferred to another country after making some adjustments on the basis of real per capita income. This adjustment is required to reflect differences in income and hence, willingness-to-pay regarding the valuation of the health damages of two countries. The following formula can be used to arrive at economic unit values of radiological health ef- fects for countries where there are no studies [19]:

$$
D_{Y}=D_{X}\left(\frac{P P P G N P_{Y}}{P P P G N P_{X}}\right)^{E}
$$

where $D_{Y}$ economic unit values of radiological health damages for country $Y, D_{X}$ economic unit values of radiological health damages for country $X, P P P G N P_{Y}$ and $P P P G N P_{X}$ is real Gross National Product per capita in purchasing power parity terms for country $\mathrm{Y}$ and $\mathrm{X}$ respectively, $E$ is the elasticity of income.

Once the total occurrence of health effect and economic unit values are calculated from Equation (2) and Equation (3) respectively; the total damage in terms of health effect $h$ is valued using VOSL or VLYL approach. $V_{h}(V O S L, V L Y L)$ can be calculated from the following formula [19]:

$$
V_{h}(V O S L, V L Y L)=N_{h} D_{h}(V O S L, V L Y L)
$$

In this study, the economic unit values for Turkey are estimated by using Canadian economic unit values of radiological health impacts since the Canada is the country that the recent economic unit values of radiological health impacts are available [8]. PPPGNP $P_{\text {Turkey }}$ and PPPGNP $P_{\text {Canada }} 8600$ US\$ and 27630 US\$ respectively, in 2000 [20]. The elasticity $(E)$ of income is assumed to be

Table 7. Economic unit values of radiological health impacts (US\$/case)

\begin{tabular}{lcc}
\hline & Canada & Turkey \\
\hline Fatal cancer VOSL & $1.73 \times 10^{6}$ & $5.38 \times 10^{5}$ \\
Fatal cancer VLYL & $7.73 \times 10^{5}$ & $2.41 \times 10^{5}$ \\
Non-fatal cancer & $5.77 \times 10^{5}$ & $1.80 \times 10^{5}$ \\
Severe hereditary effect & $1.73 \times 10^{6}$ & $5.38 \times 10^{5}$ \\
\hline
\end{tabular}


Table 8. The monetary value of the predicted health effects (US\$/y)

\begin{tabular}{lc}
\hline \multicolumn{1}{c}{ Health effect type } & Damage cost \\
\hline Fatal cancer VOSL & 8334 \\
Fatal cancer VLYL & 3733 \\
Non fatal cancer & 558 \\
Severe hereditary effects & 2167 \\
Total & $\mathbf{1 4 7 9 1}$ \\
\hline
\end{tabular}

equal to $1[8,21]$. Economic unit values of radiological health impacts for Canada and estimated values for Turkey are given in Table 7.

Based on the economic unit values of radiological health impacts (see Table 7), the valuation of the predicted health effects are calculated from Equation (4). The calculated damage costs of the radiological health effects are given in Table 8.

\section{Conclusions}

In this study, the radiation dose calculations have been carried out by the code CAP88-PC for the population living within $80 \mathrm{~km}$ radius of the Yatağan coal-fired power plant (YPP). The average of the maximum measured specific isotopes ${ }^{238} \mathrm{U},{ }^{232} \mathrm{Th}$ and ${ }^{226} \mathrm{Ra}$ in the flying ash samples are considered as radioactive sources. Based on the dose calculations, the stochastic health effects and predicted health effects have been estimated. It is seen that the total and the maximum collective effective dose equivalent rate is $0.3098 \mathrm{man} \mathrm{Sv} / \mathrm{y}$ and $0.0510 \mathrm{man} \mathrm{Sv} / \mathrm{y}$ respectively. Those values are lower than recommended by the ICRP and it does not pose any risk for public health.

The total monetary value of health risk is 14791 US $\$ / y$. The yearly total revenue of the YPP from the sales of electricity is approximately 250 million US\$ $[1,22]$. The results indicate that the predicted health effects are negligible in comparison to the economic value of the YPP.

YPP was stopped between 20 February and 20 March 1993 because of the speculations on radionuclide emissions from the plant. It was a big occasion for news media [23]. The speculations on the radionuclide emissions from the YPP and their health effects have continued since 1993. Against the speculations, there is no significant literature on the stochastic health effects and the cost of the predicted health effects from the YPP [24]. Therefore, the results of this study are very useful for ending up the speculations on the health effects and the costs of those effects.

\section{REFERENCES}

[1] General Description of Yatağan Coal Fired Power Plant, Electricity Generation Cooperation, Muğla, 2006.
[2] T. Zeevaert, L. Sweeck, and H. Vanmarcke, "The radiological impact from airborne routine discharges of a modern coal fired power plant," Journal of Environmental Radioactivity, Vol. 85, No. 3, pp. 1-22, 2006.

[3] C. Papastefanou and S. Charalambous, "On the escaping radioactivity from coal power plants (CPP)," Health Physics, Vol. 64, pp. 293-302, 1984.

[4] Radiological Impact on the UK Population of Industries Which Use or Produce Materials Containing Enhanced Levels of Naturally Occurring Radionuclides: Part I: Coal-Fired Electricity Generation, Report No: NRPBR327, National Radiological Protection Board, Chilton, 2001.

[5] A. Nakaoka, M. Fukushima, and S. Takagi, "Environmental effects of natural radionuclides from coal-fired power plants," Health Physics, Vol. 47, No. 3, pp. 407 416, 1984.

[6] B. Parks and S. P. E. Chaki, CAP88-PC Version 2.0 Updated User's Guide, Report No: EPA 402-R-00-004, Las Vegas, 2000.

[7] 1990 Recommendations of the International Commission on Radiological Protection, Report No. 60, International Commission on Radiological Protection, Pergamon Press, Oxford, 1991.

[8] Review of NucPacts: An Environmental Assessment Package, International Atomic Energy Agency, Vienna, 2003.

[9] Annual Meteorological Conditions in Yatağan 1975-2006 Periods, Turkish State Meteorological Service, Ankara, 2007.

[10] City and Village Population, Annual Growth Rate of Popupation, Surface Area and Density by Districts in Turkey, Turkish Statistical Institute, Ankara, http://www.tuik.gov.tr/PreIstatistikTablo.do?istab_id=220

[11] T. Buke, "Dose assessment around the Yatağan coal-fired power plant due to measured gross alpha radioactivity levels in flying ash," Journal of Radioanalytical and Nuclear Chemistry, Vol. 256, No. 2, pp. 323-328, 2003.

[12] S. Righi, P. Lucialli, and L. Bruzzi, "Health and environmental impacts of a fertilizer plant Part I: Assessment of radioactive pollution," Journal of Environmental Radioactivity, Vol. 82, pp. 167-182, 2005.

[13] Natural radioactivity measurements in ash-samples of the Yatağan Power Plant, Turkish Atomic Energy Authority, Ankara, 1994.

[14] T. Akyüz, S. Akyüz, A. Varinlioğlu, A. Köse, J. Eric, and D. Davies, "FT-IR, EDXRF and gamma-isotopic analyses of ashes from coal fired power plants of Turkey," Spectroscopy Letters, Vol. 29, pp. 1131-1139, 1996.

[15] G. A. Ayçık and A. Ercan, "Off-line determination of ash content directly in coal samples via-spectrometry," Applied Spectroscopy Reviews, Vol.33, pp. 237-251, 1998.

[16] Economic and Commercial Conditions of Aydın. Industry and Trade Center of Muğla, Muğla, 2007. 
[17] Economic and Commercial Conditions of Muğla, Industry and Trade Center of Muğla, Muğla, 2007.

[18] N Selçuk, A. Atımtay, O. Uslu, Ş. Cirik, H. Vurdu, G. Tuncel, Z. Kaya, M. Evirgen, and C. Yurteri, Scientific Committee Report for Kemerkoy Thermal Power Plant, Ankara, 1995.

[19] A. Markandya and R. Boyd, "Valuing the human health effects of routine atmospheric releases from nuclear facilities," International Atomic Energy Agency, Vienna, 1999.

[20] World Development Indicators (WDI), http://ddp-xt.worldbank.org.

[21] E. Liun, A. H. Kuncoro, and E. Sartono, "Environmental impacts assessment of Java's electricity generation using
SimPacts model," International Conference on Advances in Nuclear Science and Engineering in Conjunction with LKSTN, pp. 379-384, 2007.

[22] Electricity selling prices of Turkey for the year 2000, Directorate General of Turkish Electricity Distribution, 2000.

[23] M. Aslan, "A typical example of the discussion about the environmental impacts of coal fired thermal power plants in Turkey: Yatağan thermal power plant experience," Symposium on Environmental effects of Electricity Production from Coal, Ankara, 1995.

[24] T. Oğuz "Personal communications," Associate Mayor of Yatağan, 2008. 